\title{
ADOPTION OF RECOMMENDED MANAGEMENT PRACTICES BY MAIZE GROWING FARMERS TO MINIMIZE AFLATOXIN CONTAMINATION
}

\author{
JAYANTHI $M^{1} \&$ S. KALAIVANI ${ }^{2}$ \\ ${ }^{1}$ Assistant Professor, Department of Agriculture School of Agriculture \& Horticulture, KARE, Krishnankoil, India \\ ${ }^{2}$ Assistant Professor, Department AE \& RS, Tamil Nadu Agricultural University, Coimbatore, India
}

\begin{abstract}
Maize is grown both in tropical and temperate areas of the globe. Maize is one of the world's leading crops, cultivated over an area of about 148.50 million hectares. In India, it occupies third place in the cereals, following rice as well as wheat. Ant it is grown over an area of 7.59 million ha. Enhancing post-yield management as well as processing is crucial to minimize or decrease wastage and also to ensure that superior standard goods get to the trade centrers. Frequently, even when the harvests are high, manufacturers lose profit because of bad post-yield activities. The majority of farmers, traders and consumers in India are not currently aware of the aflatoxin contamination of food. In this regard the present research was formulated with the following particular targets, to analyse the extent of acquisition of management technologies in maize among farmers.
\end{abstract}

KEYWORDS: Adoption, Maize, Management Technologies \& Farmers

Received: May 24, 2020; Accepted: Jun 16, 2020; Published: Aug 05, 2020; Paper Id.: IJASRAUG202017

\section{INTRODUCTION}

India accounts for just around $2.4 \%$ of the world's geographical region and $4 \%$ of its water resources, yet must support around $17 \%$ of the world's human population as well as 15\% of their livestock. Farming is a significant part of the Indian economy, accounting for $14 \%$ of the country's GDP and roughly $11 \%$ of its exports. Approximately half of the population depends upon farming as its primary source of revenue and it's a fount of raw material for a great number of businesses. Throughout 2011-12, there has been noticed decrease in manufacturing of food grains at 259.32 million tonnes. Of the entire food grains yield, yield of cereals has been 242.23 million tonnes as well as pulses 17.09 million tonnes (Anonymous, 2012). Enhanced post-yield managing as well as processing was crucial to lessen decrease in wastage and also to guarantee that better standard goods reach the trade places. Frequently, even if the returns were high, manufacturers lost revenue because of bad post yield activities.

Several cereal and other crops were prone to fungal infection, either in the fields or during stocking. Decline of farm goods, brought on through mould development, may happen in different phases of manufacturing as well as stocking and is important concerning commerce economics, food security and also public health (Shephard, 2008). It's been predicted that $25 \%$ of the world crops have been affected by mould contamination to the degree which they can't be consumed by humans or animals (Mannon and Johnson, 1985). Mould expansion not only reduces the standard of food but also constitutes a possible threat for human health due to the creation of toxic secondary metabolites- a varied set of chemical compounds called "mycotoxins". Mycotoxins are secondary metabolites that commonly change in structure; however they share general features, such as complicated chemical structure, resistance to thermal deterioration as well as an overall inclination to persevere throughout the processing of products. 
Therefore, when formed, they are likely to end up in the final consumer goods (Waalwijk et al. 2008).

Human exposure to mycotoxins can come from ingestion of plant based foods that were polluted with toxins, the carryover of mycotoxins as well as their metabolites into animal goods like milk, meat and eggs or subjection to air and dust comprising toxins (Jarvis, 2002). Human food could be polluted with mycotoxins in different phases throughout the food chain. Food polluted with mycotoxins, while consumed by humans as well as animals, leads to mycotoxicosis and poisoning of foods and feeds, leading to death (Wagacha and Muthomi, 2008).

Aflatoxins are harmful to human health, additionally their part in hepatocarcinogenesis frequently along with hepatitis B has been well recognized (Wild and Hall, 1998; Wild and Turner, 2002). At high enough exposure levels, aflatoxins may lead to severe toxicity, and possibly death, in mammals, birds and fish, in addition to humans. The liver was the primary organ influenced, yet high degrees of aflatoxin also were located in the lungs, kidneys, brains and hearts of people dying of acute aflatoxicosis.

Maize is grown both in tropical and temperate areas of the globe. Maize is one of the world's leading crops cultivated over a region of around 148.50 million hectares with a manufacturing of about 699.30 million tonnes and productivity of 4.71 tonnes of grain /ha (USDA, 2007) and per capita maize grain consumption is $110.20 \mathrm{~kg}$. In India, it ocupies third position amid the cereals after rice, as well as wheat and it was grown over a region of 7.59 million ha with a manufacturing of 14.71 million tonnes and the average productivity is $1938 \mathrm{~kg} / \mathrm{ha}$ (Anonymous, 2007). In Tamil Nadu, maize was grown in a region of 0.86 million hectares with a production of 1.02 million tonnes as well as an average yield of $1185 \mathrm{~kg} / \mathrm{ha}$ (Season and Crop Report, 2010 - 11).

Substantial aflatoxin pollution, in corn as well as corn-based products, is noticed. Aflatoxins are found in several corn-based products like corn, corn on the cob, corn beverages, Tortillas, corn kernels, corn gluten raw, corn gluten feed, yellow corn, white corn, corn flour as well as corn flakes (Park and Liang, 1993). Bhat et al. (1997) noted that 26\% of maize kernels gathered from various regions of India have been polluted with AFB1 beyond the amount allowed by Indian standards for ingestion (30 $\mathrm{gg} \mathrm{kg-1).} \mathrm{Kpodo} \mathrm{(1996)} \mathrm{noted} \mathrm{that} \mathrm{the} \mathrm{maize} \mathrm{samples} \mathrm{gathered} \mathrm{from} \mathrm{Ghana} \mathrm{comprised} \mathrm{aflatoxins} \mathrm{at} \mathrm{levels}$ that range from 20 to $355 \mu \mathrm{g} \mathrm{kg}-1$. Waliyar et al. (2003) noted that $43 \%$ of maize samples gathered from retail stores or super markets in and around Hyderabad, Andhra Pradesh, India have been polluted with toxin with the maximum AFB1 amount of $806 \square \mathrm{g} \mathrm{kg}-1$.

Since maize was viewed to be a positive choice for varying farming in upland regions of India, its area has shown a steady increase over the past few years. Maize is grown primarily for food, fodder, feed as well as industrial operation. Over 3500 value-added goods for day to day use were obtained from maize. The poultry feed manufacturing industries are on the increase during recent years. The majority of farmers, traders and consumers in India are not currently aware of the aflatoxin contamination of food. In this regard, the present research has been formulated with the following particular aim: to analyse the extent of acquisition of management technologies in maize among farmers.

The study deals with action of maize growers and also the drawbacks in the existing systems, which would give a clear perspective about the adoption of management technologies among agriculturalists. This would help the people involved in food safety to chalk out a need-based plan. Sundar (2002) observed that, in general, selected growers had not adopted technologies recommended by TNAU with respect to selection of tubers, seed rate and spacing. The practices viz., manuring, fertilizer application and plant protection were adopted partially. Saravanan (2003) stated that majority (84.33 \%) 
of the respondents had full adoption about the application of 12.5 tons of FYM/ha during the last ploughing. Selvamathi (2003) stated that more than three-fourths (78.33\%) of the respondents adopted weed management by hand weeding followed by fertilizers $(60.00 \%)$ and seed rate $(54.17 \%)$. Anjugam (2012) indicated that more than two-fifths $(63.33 \%)$ of the respondents had medium level of adoption succeeded through 35.00 per cent of the respondents at low level as well as 2.00 per cent at high levels. Karpagam (2012) stated that more than three-fifths $(60.00 \%)$ of the respondents exhibited medium level of adoption of technologies succeeded by 15.00 per cent at low as well as 25.00 per cent at high levels.

\section{METHODOLOGY}

Among 32 districts in Tamil Nadu, Virudhunagar District was selected specifically for this study since it is among the districts where maize is cultivated in a larger area; three blocks have been chosen which rely upon maize farming. One village from each block was selected based on highest area under maize cultivation. A sample of 120 maize growers was chosen for the research by utilizing uncomplicated random sampling method. The present research had no control over the independent variables prior to producing their effect and hence the ex-post facto models have been utilized. Thus, the most efficient and consistently advocated 15 independent variables were chosen for the research viz. educational status, occupational status, farm size, area under maize cultivation, farming experience, experience in maize cultivation, farm power possession, social involvement, mass media exposure, contact with extension agency, scientific orientation, risk orientation, innovativeness, market perception and training.

In this study, adoption refers to following the technologies in maize recommended by TNAU. The list of items to evaluate the acquisition level has been established, based on discussion with scientists, as well as through citing literature. The extent of adoption of maize cultivation technologies was measured by means of adoption index. Adoption of each technology was measured on the three point continuum. Score 3 for fully adopted, score 2 for partially adopted and score 1 for not adopted was assigned. The scores acquired on individual items beneath an operation have been totalled to appear as the overall score for that operation. The scoring procedure is presented as follows.

Table 1

\begin{tabular}{|c|l|c|}
\hline S. No. & \multicolumn{1}{|c|}{ Response } & Score \\
\hline 1. & Fully adopted & 3 \\
\hline 2. & Partially adopted & 2 \\
\hline 3. & Not adopted & 1 \\
\hline
\end{tabular}

The respondents have been grouped as low, medium as well as high utilizing mean and standard deviation. For extent of acquisition level, percentage examination has succeeded in analyzing the operation wise acquisition level of respondents on management technologies in maize cultivation.

A perfectly organized interview schedule has been utilized to collect data.

\section{RESULTS AND DISCUSSIONS}

\section{Adoption of Management Technologies in Maize among Farmers}

\section{Overall Adoption of Management Technologies among Farmers}

The distribution of respondents in accordance with their entire acquisition of management technologies in maize was shown in table 1 . 
Table 2: Distribution of Respondents According to their Overall Adoption Level on Management Technologies in Maize $(\mathbf{n}=120)$

\begin{tabular}{|c|l|c|c|}
\hline S. No. & \multicolumn{1}{|c|}{ Category } & Number & Per cent \\
\hline 1. & Low & 4 & 3.33 \\
\hline 2. & Medium & 104 & 86.67 \\
\hline 3. & High & 12 & 10.00 \\
\hline \multicolumn{2}{|l|}{ Total } & $\mathbf{1 2 0}$ & $\mathbf{1 0 0 . 0 0}$ \\
\hline
\end{tabular}

From the data in table 1, it could be observed that majority $(86.67 \%)$ of the respondents are found at medium level succeeded by high (10.00\%) and low (3.33\%) levels of overall adoption of management technologies in maize.

\section{Management Technology Wise Adoption Level among Maize Farmers}

Efforts were made to locate the management technology wise adoption levels of respondents and results were analyzed and distribution of respondents according to their management technology wise acquisition levels was shown in table 2

Table 3: Distribution of Respondents According to their Management Technology Wise Adoption Levels (n=120)

\begin{tabular}{|c|c|c|c|c|c|c|c|}
\hline \multirow{3}{*}{ S. No. } & \multirow{3}{*}{ Management Technologies } & \multicolumn{6}{|c|}{ Extent of Adoption } \\
\hline & & \multicolumn{2}{|c|}{$\begin{array}{c}\text { Fully } \\
\text { Adopted }\end{array}$} & \multicolumn{2}{|c|}{$\begin{array}{l}\text { Partially } \\
\text { Adopted }\end{array}$} & \multicolumn{2}{|c|}{$\begin{array}{c}\text { Not } \\
\text { Adopted }\end{array}$} \\
\hline & & No. & $\%$ & No. & $\%$ & No. & $\%$ \\
\hline I & \multicolumn{7}{|l|}{ Seed Rate } \\
\hline 1. & Seed rate is $8 \mathrm{~kg} / \mathrm{acre}$ & 110 & 91.70 & 9 & 7.50 & 1 & 0.83 \\
\hline II & \multicolumn{7}{|l|}{ Seed Rate } \\
\hline 2. & $\begin{array}{l}\text { Seed is treated with Azospirillum } 50 \mathrm{~g} / \mathrm{kg}, 2 \% \mathrm{KH} 2 \mathrm{PO} 4 \text { and } \\
\text { Bavistin } 2 \mathrm{~g} / \mathrm{kg}\end{array}$ & 2 & 1.67 & 1 & 0.83 & 117 & 97.50 \\
\hline III & \multicolumn{7}{|l|}{ Irrigation } \\
\hline 3. & Seeding stage & 120 & 100.00 & - & - & - & - \\
\hline 4. & Knee-height stage & 120 & 100.00 & & & & \\
\hline 5. & Tasseling stage & 120 & 100.00 & & & & \\
\hline 6. & Silking stage & 120 & 100.00 & & & & \\
\hline 7. & Grain filling stage & 120 & 100.00 & & & & \\
\hline IV & \multicolumn{7}{|c|}{ Pest Management } \\
\hline 8. & Furadon will be applied at 20 DAS to control the stem borer & 2 & 1.67 & 76 & 63.33 & 42 & 35.00 \\
\hline 9. & $\begin{array}{l}\text { Carbaryl } 4 \text { G } 20 \mathrm{~kg} / \mathrm{ha} \text { (or) Carbaryl } 50 \mathrm{WP} 1 \mathrm{~kg} / \mathrm{ha} \text { (or) } \\
\text { Quinolphos } 5 \text { G } 15 \mathrm{~kg} / \mathrm{ha} \text { used to control the stem borer }\end{array}$ & 1 & 0.83 & 6 & 5.00 & 113 & 94.17 \\
\hline 10. & $\begin{array}{l}\text { Carbaryl } 10 \% \text { D } 25 \mathrm{~kg} / \mathrm{ha} \text { (or) Carbaryl } 50 \mathrm{WP} 1.0 \mathrm{~kg} / \mathrm{ha} \text { is } \\
\text { used to control the cob borer }\end{array}$ & 1 & 0.83 & 1 & 0.83 & 118 & 98.33 \\
\hline V & \multicolumn{7}{|l|}{ Harvesting } \\
\hline 11. & $\begin{array}{l}\text { When the sheath covering cobs turn yellow and dry, harvest the } \\
\text { crop }\end{array}$ & 11 & 9.17 & 106 & 88.33 & 3 & 2.50 \\
\hline 12. & Burn all the mouldy cobs in the field & 6 & 5.00 & 99 & 82.50 & 15 & 12.50 \\
\hline VI & \multicolumn{7}{|l|}{ Post-Harvest } \\
\hline 13. & Sort diseased and pest damaged cobs in the field & 33 & 27.50 & 85 & 70.83 & 2 & 1.66 \\
\hline 14. & Dry the cobs on the polythene sheet & 1 & 0.83 & 6 & 5.00 & 113 & 94.17 \\
\hline VII & \multicolumn{7}{|l|}{ Storage } \\
\hline 15 & $\begin{array}{l}\text { The moisture content for long term storage of maize kernel is } \\
\text { below } 13 \%\end{array}$ & 8 & 6.67 & 27 & 22.50 & 85 & 70.83 \\
\hline
\end{tabular}

It can be concluded from table 2 that hundred per cent of the respondents had fully adopted irrigation management followed by over ninety per cent $(91.70 \%)$ of the respondents who had fully adopted the seed rate per acre. It could be further observed from result that $88.33,82.50,70.83$ and 63.33 per cent of the respondents was partially adopted the correct period of harvest, burning the mouldy cobs in the field itself, sorting the diseased and damaged cobs and applying furadon 
to control the stem borer respectively. Nearly one fourth $(22.50 \%)$ of the respondents had partially adopted the maintenance of grain moisture content.

Also it could be interpreted from the results that 98.33 per cent of the respondents had not applied pesticides to control the cob borer followed by 97.50 per cent who had not adopted the seed treatment. Also it is observed from the result that an equal per cent of respondents $(94.17 \%)$ had not adopted stem borer control measures and drying the cobs on the polythene sheets respectively. It is evident from the present study that the respondents had poor adoption of management technologies like seed treatment with insecticides, application of insecticides to control corn borers and stem borers. Insect harm to growing maize ears may crucially raise aflatoxin levels in pre-yield ears (Widstrom et al. 1976; McMillian et al. 1985). Harm by the corn ear worm (Helicoverpa zea), fall armyworm (Spodoptera frugiperda), European corn borer (Ostrinia nubilalis) as well as maize weavils (Sitophilus zeamais) might lead to greater amount of aflatoxin pollution. These insect raise A. flavus infection and aflatoxin contamination by feeding on and harming developing kernels as well as by transmitting A. flavus conidia through air. Windham et al. (1999) demonstrated that South Western Corn Borer (SWCB) may significantly raise aflatoxin amount while integrated with A. flavus.

\section{CONCLUSIONS}

Very few respondents had consulted agricultural officials at the time of cultivation and hence a greater number of gross root level agricultural extension workers may be deputed to the potential villages to increase the adoption per cent of maize management technologies among farmers. The importance of pest management practices during pre-harvest and post-harvest stages may be stressed among the farmers.

\section{REFERENCES}

1. Anjugam, K. 2012. Knowledge and adoption of post-harvest technologies among paddy farmers - An analytical study. Unpub. M.Sc. (Ag.) Thesis, AC \& RI. TNAU, Coimbatore.

2. Anonymous, 2007. Season and crop report. Department of Agriculture, TNAU. Coimbatore.

3. Anonymous, 2012. State of Indian Agriculture 2012-13, Directorate of Economics and Statistics, Department of Agriculture and Cooperation, Ministry of Agriculture, Government of India, New Delhi.

4. Bhat, R. V., S. Vasanthi and B.S. Rao. 1996. Aflatoxin B1 contamination in groundnut samples collected from different geological regions of India: a multicenter study. Food Additives and Contaminations, 13, 325-337.

5. Fapohunda, Stephen Oyedele, et al. "Anti-Aflatoxigenc Potentials of Two Nigerian Herbs on Albino Rats." J. Biol. Environ. Sci 3.9 (2009): 81-90.

6. Jarvis, B. B. 2002. Chemistry and toxicology of molds isolated from water-damaged buildings. $\quad$ Mycotoxins and Food Safety; Adv. Expt. Med. Biol., 504:43-52.

7. Jha, S. H. I. P. R. A., and A. K. Srivastava. "Antibacterial, antifungal and pesticidal activity of plant Morus alba. A novel approach in post-harvest Technology." International Journal of Agricultural Science and Research 3.1 (2013): 157-162.

8. Karpagam, P. 2012. Technology adoption and marketing behaviour of turmeric growers. Unpub. M.Sc. (Ag.) Thesis, AC \& RI, TNAU, Coimbatore.

9. Kpodo, K.A. 1996. Mycotoxins in maize and fermented maize products in southern Ghana. In: $\quad$ Cardwell $\quad$ KF, $\quad$ ed. Proceedings of the Workshop on Mycotoxins in Foods in Africa, November 6-10, 1995, Cotonou, Benin. Ibadan, Nigeria: International Institute for Tropical Agriculture (IITA), 33-5. 
10. Kumar, Manish, and Ahmad Masood. "The Biological Effects of Crude Aflatoxin B1 on Mustard (Brassica Juncea) Varieties." International Journal of Botany and Research (IJBR) 9. 1, Jun 2019, 15-20

11. Mannon. J. and E. Johnson. 1985. Fungi down on the farm. New Scientist, 105:12-16

12. Nkunda, Dominique Savio. "Effect of Purdue improved crop storage (pics) bags on the quality of stored beans (Phaseolus vulgaris)." Int. J. of Agric Science and Research 8.2 (2018): 49-54.

13. Park D. L. and B. Liang. 1993. Perspectives on aflatoxin control for human food and animal feed. Trends in Food Science \& Technology, 4: 334-243.

14. Selvamalathi. 2003. A study on shift in cultivation from cotton pulse in rainfed tract. unpub. M.Sc. (Ag.) Thesis, AC \& RI, TNAU, Madurai.

15. Shephard, G. S. 2008. Impact of mycotoxins on human health in developing countries. Food. Add. And Cont. 25:146-151.

16. Sundar, A. 2002. Medicinal plants - Golden Gift of mankind, Plant Horti Tech., 3(3): 55-56

17. Waalwijk. C., S. H. Koch., E. Ncube., J. Allwood., B. Flett., I. de Vries and G. H. J. Kema. 2008. Quantitative detection of Fusarium spp. and its correlation with fumonisin content in maize from South African subsistence farmers. World Mycotoxin Journal, 1(1): 39-47.

18. Wagacha, J. M. and J. W. Muthomi. 2008. Mycotoxin problem in Africa: Current status, implications to food safety and health and possible management strategies. Int. J. Food Microbiol. 124:1-12.

19. Waliyar, F., S. V. Reddy., K. Subramaniam., T. Y. Reddy., K. R. Devi., P. Q. Craufurd and T. R. Wheeler. 2003. Importance of mycotoxins in food and feed in India. Aspects $\quad$ Appl. Biol. 68, 147-154.

20. Widstorm, N. W., E. B. Lillehoj., A. N. Sparks and W. F. Kwolek. 1976. Corn earworm with insecticide. J. Econ. Entomol. 69:677-679.

21. Wild, C. P. and A. J. Hall. 1998. Hepatitis B virus and liver cancer - unanswered questions. Cancer Surveys: Infections and Human Cancer 33:35- 54.

22. Wild, C. P. and P. C. Turner. 2002. The toxicology of aflatoxins as a basis for public health decisions. Mutagenesis 17:471- 481 .

23. Windham, G. L., W. P. Williams and F. M. Davis. 1999. Effects of the southwestern corn borer on Aspergillus flavus kernel infection and aflatoxin accumulation in maize hybrids. Plant Dis. 83:535-540. 